\title{
ANALISIS PERLAKUAN AKUNTANSI DAN PELAPORAN BELANJA BARANG DAN JASA PADA DINAS PEMBERDAYAAN PEREMPUAN DAN PERLINDUNGAN ANAK PROVINSI SULAWESI UTARA
}

\author{
Claudya Kojongian ${ }^{1}$, Harijanto Sabijono ${ }^{2}$, Sonny Pangerapan ${ }^{3}$ \\ ${ }^{1,2,3}$ Jurusan Akuntansi, Fakultas Ekonomi dan Bisnis, Universitas Sam Ratulangi, Jl. Kampus Bahu, Manado, \\ 95115, Indonesia
}

E-mail : claudyakojongianclau @gmail.com

\begin{abstract}
The purpose of this study to Analyses the Accounting Treatment and the Goods and Service spending on Department of Empowerment of Women Employment and Protection of Children of North Sulawesi Province in accordance with applicable regulations. Accounting treatment is the treatment on goods and service include recognition, measurement, presentment, and disclosure. The purpose of this study to determine the accounting treatment on Department of Empowerment of Women Employment and Protection of Children of North Sulawesi Province. The methods used in this research is a qualitative descriptive. The results obtained that The Accounting Treatment of Goods and Service in Department of Empowerment of Women Employment and Protection of Children of North Sulawesi Province is already Accrual based and the reporting has been arranged in accordance with Minister of Home Affairs Regulations No. 64 of 2013 concerning Implementation of accrual Based Government Accounting Standards.
\end{abstract}

Keyword: Analyses, Accounting treatment, Reporting, Goods and service spending.

\section{PENDAHULUAN}

Pengeluaran pemerintah di daerah dalam menjalankan atau melaksanakan anggaran pendapatan dan belanja daerah atau yang disebut APBD dan juga dikenal dengan sebutan belanja daerah adalah merupakan suatu faktor pendukung pertumbuhan ekonomi di daerah, oleh karena itu belanja daerah lebih dikenal sebagai instrument kebijakan fiskal yang dikerjakan oleh pemerintah di daerah.

SKPD atau Satuan Kerja Perangkat Daerah adalah salah satu bagan dari pemerintah daerah dan memiliki tugas untuk melaksanakan tugas-tugas sebagai pemerintah, baik dengan cara langsung dan dengan cara tidak langsung. SKPD dalam pelaksanaan tugas tersebut akan diberikan dana dalam bentuk anggaran. Sebabnya yang termasuk dalam kepala-kepala SKPD akan disebut juga sebagai pengguna anggaran tersebut. Dinas pemberdayaan perempuan dan Anak Provinsi Sulawesi Utara yang adalah satuan kerja perangkat daerah (SKPD) salah satu tugasnya adalah membuat suatu pertanggungjawaban atas kewenangan yang telah atau akan dilaksanakan berdasarkan dengan Permendagri No. 64 Tahun 2013 tentang penerapan standar akuntansi pemerintahan serta dalam Peraturan Pemerintah Nomor 71 Tahun 2010 tentang standar akuntansi pemerintahan berbasis akrual.

\section{TINJAUAN PUSTAKA}

Pengertian Akuntansi. Akuntansi merupakan salah satu seni dalam pencatatan, proses menggolongan, serta merupakan proses meringkas menggunakan cara-cara yang dapat dimengerti dan dapat dilihat dan dihitung dalam wujud mata uang, dalam berbagai transaksi yang ada dan juga kejadian-kejadian dalam kegiatan yang berkaitan dengan keuangan perusahaan (Tanor, 2015). 
Akuntansi Pemerintahan. Agustiawan (2013) mengemukakan bahwa: "Standar akuntansi pemerintah adalah prinsip-prinsip akuntansi yang diterapkan dalam menyusun dan menyajikan laporan keuangan pemerintah, yang terdiri atas Laporan Keuangan Pemerintah Pusat (LKPP) dan Laporan Keuangan Pemerintah Daerah (LKPD), dalam rangka transparansi dan akuntabilitas penyelenggaraan akuntansi pemerintahan, serta peningkatan kualitas LKPP dan LKPD".

Standar Akuntansi Pemerintahan. Standar Akuntansi Pemerintahan Berbasis Akrual Pernyataan Nomor 01 menyatakan kalau akuntansi pemerintahan berbasis akrual adalah suatu basis akuntansi juga mengakui adanya pengaruh-pengaruh dalam transaksi dan di dalam peristiwa-peristiwa lain yang ketika transaksi itu terjadi atau dan peristiwa saat itu terjadi dengan tidak adanya perhatian di saat kas dan setara kas didapat dan atau diberikan.

Kedudukan Akuntansi Pemerintahan. Akuntansi terbagi 2, yaitu: Akuntansi Komersial dan Akuntansi Sektor Publik. Akuntansi Sektor Publik di bagi atas : (1) akuntansi Pemerintahan; (2) akuntansi Sosial.

Pelaporan. Pelaporan adalah salah satu bentuk pertanggung-jawaban dalam satu kegiatan yang dilakukan dan tindakan yang dilakukan. Laporan keuangan menurut Wahyudiono (2014:10) merupakan bentuk pelaporan dari pertanggungjawaban menager atau biasanya pimpinan-pimpinan dalam perusahaan atas dasar pengelolaan perusahaan yang dapat dipertanggungjawabkan kepada pihak-pihak lain luar perusahaan tersebut.

Sistem Akuntansi Pemerintah Daerah. Dalam mengembangkan sistem akuntansi ditingkat pemerintah daerah, Sistem Pemerintah di daerah-daerah telah diupayakan dilakukan dengan Sistem Akuntansi dan Pengendalian Anggaran sejak tahun 1986. Adanya suatuperubahan yang begitu penting yang konsidental akan ada merupakan reformasi dalam bidang-bidang keuangan dalam negara.

Sistem Akuntansi Satuan Kerja Pemerintah Daerah. Didalam struktur-struktur pemerintah didaerah-daerah, yang dimaksud dengan satuan kerja adalah entitas-entitas dalam akuntansi didalamnua mempunyai kewajiban atau wajib untuk melakukan pencatatanpencatatan terhadap transaksi-transaksi yang terlaksana di dalam lingkup lingkungan skpd tersebut.

Konsep Belanja Pemerintah. Yang dimaksud dengan belanja meruakan salah satu jenis biaya yang disebabkan atau timbulnya karena adanya dampak secara langsung kepada berkurangnya saldo yang ada di kas ataupun uang entitas yang ada di bank. Dalam belanja barang dan juga jasa adalah termasuk semua yang termasuk dalam pembayaran oleh pemerintah dengan adanya pertukaran antara barang dan jasa, bisa bentuknya dalam upah atau gaji yang diberikan kepada pegawai dan atau bisa dalam proses transaksi pembelian lainlain berupa barang dan jasa.

Belanja Langsung. Kelompok belanja langsung merupakan kelompok belanja-belanja yang telah dianggarkan atau diketahui dan di catat yang terkait dengan cara langsung berupa pelaksanaan program-programya serta kegiatan-kegiatannya.

Belanja Tidak Langsung. Belanja-belanja tidak langsung adalah daftar belanja yang telah dan akan dianggarkan yang tidak terkait dengan cara yang langsung atas pelaksanaanpelaksanaan programnya serta kegiatannya.

\section{METODE PENELITIAN}

Jenis Penelitian. Dalam penelitian ini jenis data yang dapat digunakan adalah berupa data kualitatif serta data kuantitatif. Data kualitatif yang dimaksud dapat seperti keterangan bisa dalam bentuk penjelasan dalam kata perkata serta tidak hanya dinilai di dalam standar numerik yang dapat seperti data-data tentang Peraturan Pemerintah atau PP tentang standar akuntansi pemerintah, berupa pencatatan serta pelaporan laporan akuntansi atas barang dan jasa, dan pada data kuantitatif dapat dijelaskan mengenai laporan-laporan keuangan pada 
Dinas Pemberdayaan Perempuan dan Perlindungan Anak Provinsi Sulawesi Utara.

Tempat dan Waktu Penelitian. Penelitian dilaksanakan pada Dinas Pemberdayaan Perempuan dan Perlindungan Anak Provinsi Sulawesi Utara yang bertempat di Jl. 17 Agustus, Kota Manado, Sulawesi Utara. Dalam penelitian ini, waktu Penelitian mulai pada bulan Maret sampai dengan bulan Juni 2018.

Prosedur Penelitian : (1) mengidentifikasi adanya permasalah; (2) menentukan Objek di mana akan dilakukan penelitian; (3) menyusun proposal untuk diteliti; (4) mengumpulan data dan menganalisa semua data; dan (5) hasil dari penelitian.

Jenis, Sumber dan Metode Pengumpulan data. Dalam penelitian ini, penulis akan memakai data kualitatif sebagai dasar untuk menganalisis bagaimana perlakuan akuntansi belanja barang dan jasa, mekanisme pelaporan, serta faktor-faktor apa sajakah yang menjadi kendala dalam pelaporan belanja barang dan jasa pada Dinas Pemberdayaan Permpuan dan Perlindungan Anak Provinsi Sulawesi Utara. Dalam penelitian yang dilakukan oleh peneliti saat ini, Sumber data-data untuk dapat diproses dalam penelitian ini adalah data primer dan sekunder. Data primer berupa data hasil wawancara yang dilakukan kepada kepala sub bagian umum. Sedangkan data sekunder merupakan bahan informasi-informasi mengenai instansi pemerintahan yaitu kantor yang dimaksud bisa dalam bentuk arsip-arsip ataupun buku-buku serta dapat melalui studi kepustakaan dengan cara mempelajari referensi yang relevan.

\section{HASIL ANALISIS DAN PEMBAHASAN}

4.1. Hasil Analisis

1. Klasifikasi belanja barang dan jasa pada Dinas Pemberdayaan Perempuan dan Perlindungan Anak Provinsi Sulawesi Utara

Belanja Tidak Langsung. Belanja tidak langsung pada Dinas Pemberdayaan Perempuan dan Pelindungan Anak Provinsi Sulawesi Utara meliputi: (a) belanja untuk pegawai; (b) belanja untuk subsidi; (c) belanja untuk hibah; dan (d) belanja untuk bantuan sosial.

Belanja Langsung. Belanja langsung pada Dinas Pemberdayaan Perempuan dan Pelindungan Anak Provinsi Sulawesi Utara terbagi atas: (a) belanja operasional; (b) belanja modal; (c) belanja tak terduga; dan (d) belanja barang dan jasa.

2. Perlakuan Akuntansi Belanja Barang dan Jasa pada Dinas Pemberdayaan Perempuan dan Perlindungan Anak Provinsi Sulawesi Utara

Adapun perlakuan akuntansi atas barang dan jasa pada Dinas Pemberdayaan Perempuan dan Perlindungan Anak Provinsi Sulawesi Utara adalah sebagai berikut:

(a) pengakuan; (b) pengukuran; (c) penyajian; dan (d) pengungkapan.

3. Pelaporan Belanja Barang dan Jasa pada Dinas Pemberdayaan Perempuan dan Perlindungan Anak Provinsi Sulawesi Utara

Berdasarkan penelitian yang dilakukan setelah kegiatan belanja barang dicatat, maka pelaporan belanja barang dan jasa mempertanggungjawabkan dengan menerbitan Surat Pertanggungjawaban.

\subsection{Pembahasan}

1. Analisis perlakuan akuntansi atas belanja barang dan jasa pada Dinas Pemberdayaan Perempuan dan Perlindungan Anak Provinsi Sulawesi Utara

Sesuai dengan penelitian yang telah dilaksanakan didapatkan bahwa perlakuan akuntansi atas belanja barang dan jasa pada Dinas Pemberdayaan Perempuan dan Perlindungan Anak Provinsi Sulawesi Utara berbasis akrual sebagaimana yang diatur dalam Permendagri Nomor. 64 Tahun 2013 tentang Penerapan Standar Akuntansi Pemerintahan Berbasis Akrual, di mana dalam Standar Akuntansi Pemerintahan ini mengatakan semua pendapatan, biaya, aset, hutang, serta ekuitas yang di pelaporan keuangan berbasis akrual, serta mengakui pendapatan, belanja dan pembiayaan dalam pelaporan yang dilaksanaan 
penganggaran sesuai dengan apa yang ditetapkan di anggaran pendapatan belanja untuk daerah. Adapun Pencatatan belanja barang dan jasa pada Dinas Pemberdayaan Perempuan dan Perlindungan Anak Provinsi Sulawesi Utara yang dicatat oleh aplikasi adalah sebagai berikut:

Tabel 4.1

Jurnal belanja barang dan jasa pada Dinas Pemberdayaan Perempuan dan Perlindungan Anak Provinsi Sulawesi Utara

\begin{tabular}{|c|c|c|}
\hline Nama Akun & Debet & Kredit \\
\hline Belanja barang dan jasa & XXX & \\
\hline R/K PPKD & & XXX \\
\hline
\end{tabular}

Dari tabel 4.1 menunjukkan bahwa belanja barang dan jasa ada di sisi debet sedangkan, $\mathrm{R} / \mathrm{K}$ PPKD berada pada sisi kredit.

Tabel 4.2

Jurnal Perjalanan Dinas

\begin{tabular}{|c|c|c|}
\hline & & \\
Nama akun & Debet & Kredit \\
\hline Belanja perjalanan & XXX & \\
\hline RK/PPKD & & XXX \\
\hline
\end{tabular}

Dari tabel 4.2 menunjukkan bahwa belanja perjalanan dicatat pada sisi debet sedangkan, RK/PPKD berada pada sisi kredit.

Tabel 4.3

Jurnal Pemeliharaan

\begin{tabular}{|c|c|c|}
\hline Nama akun & Debet & Kredit \\
\hline Belanja pemeliharaan & XXX & \\
\hline RK/PPKD & & XXX \\
\hline
\end{tabular}

Dari tabel 4.3 menunjukkan bahwa belanja pemeliharaan berada pada sisi debet dan RK/PPKD berada pada sisi kredit.

\section{Analisis Pelaporan Belanja Barang dan Jasa Pada Dinas Pemberdayaan} Perempuan dan Perlindungan Anak Provinsi Sulawesi Utara

Berdasarkan penelitian dilakukan bahwa pelaporan belanja barang dan jasa dalam Dinas Pemberdayaan Perempuan dan Perlindungan Anak Provinsi Sulawesi Utara mengacu pada peraturan yaitu Permendagri No.64 Tahun 2013 tentang Penerapan Standar Akuntansi Pemerintahan Berbasis Akrual, di mana Laporan Realisasi Angaran merupakan laporan untuk menyediakan semua realisasi pendapatan LRA, transfer, beserta belanja, surplus/defisit-LRA, juga pembiayaan, dan sisa lebih atau kurang pembiayaan dari penganggaran, yang tiap-tiap di bandingkan dengan anggarannya untuk satu periode.

\section{KESIMPULAN DAN SARAN}

\subsection{Kesimpulan}

Setelah melihat data-data yang diperoleh mengenai Pencatatan dan Pelaporan belanja barang dan jasa yang sudah diuraikan pada tiap bab-bab sebelumnya, maka penulis akan menyimpulkan kesimpulan sebagai berikut: 
1. Analisis perlakuan belanja barang dan jasa pada Dinas Pembardayaan Perempuan dan Perlindungan Anak telah sesuai dengan peraturan, yaitu Pemendagri Nomor 13 Tahun 2006 Tentang Pengelolaan Keuangan Daerah yang telah diubah menjadi Peraturan Menteri Dalam Negeri No. 64 Tahun 2013 Tentang Standar Akuntansi Pemerintahan Berbasis Akrual. Perlakuan akuntansi tersebut meliputi pengakuan, pengukuran, penyajian, dan pengungkapan.

2. Pelaporan belanja barang dan jasa sudah sesuai dengan Standar Akuntansi Pemerintahan yaitu Permendagri No. 64 Tahun 2013 tentang Standar Akuntansi Pemerintahan Berbasis Akrual. Di mana laporan pertanggungjawaban pada Dinas Pemberdayaan Perempuan dan Perlindungan Anak Provinsi Sulawesi Utara dilaporkan dalam bentuk CaLK, LRA, dan LO.

\subsection{Saran}

Berdasarkan penelitian yang dilaksanakan, maka beberapa hal yang disarankan yaitu:

1. Sekiranya Dinas Pemberdayaan Perempuan dan Perlindungan Anak Provinsi Sulawesi Utara selalu mengacu pada aturan/peraturan yang ada supaya Pengelolaan Keuangan Daerah dapat mewujudkan tujuannya dengan baik dan efektif.

2. Terus menambah pengetahuan mengenai akuntansi dengan mengikuti pelatihan teknis yang diselenggarakan pemerintah agar mempermudah dalam proses pengelolaan keuangan daerah khususnya belanja.

\section{DAFTAR PUSTAKA}

Agustiawan Lasoma, Vicky 2013. Pengaruh Standar Akuntansi Pemerintahan (SAP) Terhadap Kualitas Laporan Keuangan Pemerintah Daerah. Jurnal Vol 1 No 1. Universitas Negeri Gorontalo. Gorontalo.

Dissanayaka, DKK. 2015. "The Development Of Public Sector Accounting And Financial Reporting In Sri Lanka"

Dunia, F.A. 2013. Pengantar Akuntansi. Edisi 4. Fakultas Ekonomi Universitas Indonesia. Jakarta

Meirene, Anggela. 2014. Perlakuan akuntansi belanja modal pada DPPKAD Pemda Kota Palu. Manado.

Pajow, Ria. 2015. Analisis pencatatan dan pelaporan keuangan pada Unit Pelaksana Teknis Dinas di Pemerintah Provinsi Sulawesi Utara. Manado.

Pontoh, Winston. 2013. Akuntansi Konsep dan Aplikasi. Halaman Moeka, Jakarta Barat.

Pujiyanti, Fera. 2015. Akuntansi Dasar. Penerbit: Lembar Pustaka Indonesia. Tangerang.

Priyanti, Novi. 2013. Pengantar Akuntansi. Penerbit PT. Indeks, Jakarta.

Sukmadinata, Nana Syaodi. 2013. Metode Penelitian Pendidikan. Bandung: PT Remaja Rosdakarya

Suwardjono. 2014. Teori Akuntansi (Perekayasa Pelaporan Keuangan) Edisi Ketiga. Yogyakarta: BPFE

Sugiono. 2014. Metode Penelitian Pendidikan Kuantitatif dan Kualitatif. Bandung: Graha Ilmu

Tanor. 2015. “Analisis Laporan Keuangan Dalam Mengukur Kinerja Keuangan Pada PT. Bank Artha Graha International Tbk" Jurnal EMBA.

Wahyudiono, Bambang. 2014. Mudah Membaca Laporan Keuangan. Jakarta: Penerbit Raih Asa Sukses 